done at sufficiently short intervals to make it of value. It cannot be done haphazard; a list must be kept and cases noted to attend at suitable intervals.

\section{The Hospitals.}

When we consider children who have come under the purview of the hospitals or infirmaries directly, we find that they have been dismissed to their homes and gone back to school or chronic invalidism. A hospital register would require to be kept of all such cases, and a method evolved for their periodic examination. Unless someone accepts responsibility for these, any re-examination is apt to be perfunctory. Advice sent to the school would, of course, allow of a certain control, but, as we have seen, this is apt to be unsatisfactory.

We have now various groups of children whose treatment is being supervised by different people in the same area, and if complications arise these children will mostly gravitate to the hospitals for indoor treatment.

If we could ensure co-operation between the school service, general practitioners, and hospital authorities, a supervisory centre run in conjunction with a hospital would appear to be the most appropriate solution. One such oentre has been in operation for a year and has received the blessing and some support from the Rheumatic Heart Disease Subcommittee. I refer to the one at Paddington Green Children's Hospital, under the charge of the secretary of the subcommittee, Dr. Reginald Miller. in the official report of this centre (Britisi Mrdical Journal, Supplement, December 10th, 1927, p. 223) certain facts should be noted. It is a supervisory, not a treatment, centre; it works in close association with the hospital, the school medical service; the public health service, and the general practitioner, and it does not interfere with the work of the general practitioner. The value of such a centre is seen in the numbers who have been found requiring, and who have been recommended for, treatment. About a quarter of the cases had active infection and about the same number required tonsillectomy, and all these were referred to hospital or to their family doctor. Others have been referred to heart homes or to schools for physically defective children, and of course a large number are still under regular supervision.

Another benefit from such a centre is that it affords an opportunity of educating the parents in the significance of certain signs of ill health. On the reverse of the patient's card are printed the following suggestions on the care of rheunatic children

\section{On the Care of Rheumatic Children.}

1. Rheumatism is caused by infection by a germ, and is a common disease of children, in whom it of ten attacks the heart. This is the great danger of the disease. Rheumatism is the commonest cause of heart disease in children.

2. Rheumatic attacks of all sorts often start with a sore throat.

A sore throat in a rheumatic child is always a dangerous symptom.

3. Common symptoms of rheumatism in children are :

Sore throat.

Pains in muscles.

Painful joints.

Paleness.

Shortness of breath.

Fidgetiness or nervousness.

4. Chorea, or St. Vitus's dance, is rheumatism attacking the brain. Its chief danger is the tendency for the heart to be injured at the same time. Unusual nervousness, disturbed sleep, fidgety movements, or a tendency to drop things may be warnings of St. Vitus's dance.

5. Rheumatic heart disease is of ten painless and may only be discoverable by a doctor's examination.

6. If the heart has been injured by rheumatism, its recover is very slow, and permanent harm may be done by letting the child resume an ordinary life before recovery is satisfactory.

7. An occupation in life for a child with heart disease requires very careful choice.

8. Rest is very necessary for rheumatic children. They should always be put to bed early, and they should be made to lie down during the day if they seem at all tired or if there is any aching of the limbs.

9. Damp is bad for rheumatism; basements are dangerous. 9. Damp is bad for rheumatism; basements are dangerous. available. If they get wet, their clothes should be taken off and dried at once. Watertight boots are especially important.

10. Rheumatism tends to recur, especially in the winter months. Similar suggestions have been printed in other parts of the country for the information of teachers and parents, and have proved useful.
It will be obvious that local conditions regarding density of population must determine to a certain extent the best method to be adopted in any locality. Further, any scheme to be efficient implies the presence in the locality of some public-spirited medical men. In certain parts it might be found most suitable to staff such a centre from a roster of practitioners. In others a hospital physician might take charge. By the class most attacked by the disease payment is not going to be made. The public have' not yet been educated to the standard of individual payment for professional attendance when they think they are well. There is, however, much to commend the work, and if local hospitals would provide the facilities no doubt each town could provide one or more who would be willing to give the time necessary to this supervision.

Then the goodwill and co-operation of the school medical service and the general practitioners in the district ought to be secured. If the Branch could stimulate interest so as to honeycomb the county with enthusiastic investigators, in addition to the immediate good of the children much useful information would be accumulated if uniform records were employed. Such a scheme is at present under consideration in the West of England, and a scheme of voluntary notification of rheumatic heart disease has been suggested.

Possible Immediate Action.

Before closing these remarks, I should like to emphasize two lines along which I think immediate practical good will follow. One is the education of all those coming in contact with children in the special liability of children to this infection, in the conditions which as far as we knoty predispose to it, and the indications of ill health which warrant medical attention. The other is the need for prolonged after-care and the provision of suitable residential hospital schools or rest homes-call them what you will-where a healthful environment, modified recreation, and general education can be provided for more or less indefinite periods.

The report of the Medical Research Council on "Social Conditions and Acute Rheumatism," published this year, while not agreeing in all details with the report of the Association's subcommittee, closes its preface with this sentence, which has our cordial support: "The plain need for organized after-care offers an urgent but soluble problem of preventive medicine, too long neglected, and every motive of humanity and wise economy should impel the community to provide the after-care as rapidly as possible."

${ }^{1}$ Britisit Medical Journal, SUPplement, July 3rd, 1926. 2 Ibid, April 16 th, 1927.

\section{FIELD VISION AND NEAR VISION.*}

FRERLAND FERGUS, M.D., LL.D., HONORARY SURGEON, EYE INFIRMARY, GLASGOW.

THE Royal Philosophical Society of Glasgow in 1895 gave me an opportunity of publishing my views on the testing of the eyesight of seamen. The subject was discussed at that timo chiefly from two points of view-namely, the testing of the colour sense and the testing of the light sense. The communication was largely a criticism of a report by a departmental committee of the Board of Trade; the net result of that discussion was that new regulations for the testing of eyesight which were about to be issued were withdrawn after the paper which I contributed to this society was, in great part, published in the Liverpool Journal of Commerce.

I have no intention of going back on that controversy further than to say that, so far as I am aware, the testing of the light sense has not yet been introduced in the examination of seamen. As a result of that controversy coloured lights are now largely used in examining the eyesight of seamen, as is also Edridge-Green's colour testing apparatus, and that notwithstanding the strenuous advocacy of Holmgren's wools by the late Sir W. de W. Abney

* An address given to the Royal Philosophical Society of Glasgow. 
in the official report to which I have referred. He objected to coloured lanterns being used for testing, on the ground that the light emitted by any coloured lamp was not a pure light; forgetting all the while that the same objection is applicable-and perhaps more strongly so-to the coloured skeins.

At present 1 desire to discuss some other functions of vision which aro classed under the designations of field vision, visual acuteness, and form sense; perhaps it is legitimate to add to these perception of movement.

It may materially help to elucidate my subject if $I$ call attention to the difference between visual acuteness and field rision. A simple experiment will at once show the difference. I am going to ask the learned chairman of the meeting to look at a single word in the centre of a page of print. He will find that, so long as he looks steadily at the selected word, he is quite unable to read any other word on the page. The fact that he can read the selected word depends on the circumstance that its image is made at the macula of the retina, and hence visual acuteness is sometimes spoken of as macular vision. Such a designation may not be strictly accurate, but still no serious harm can arise from our regarding "macular vision" and "visual acuteness" as practically synonymous. The term "visual acnteness" is perhaps more appropriatély used as indicating a measurement of the sharpness of macular vision possessed by any eye.

To return to the experiment: while the chairman discovers that so long as he looks fixedly at one word he is unable to read any other word on the page, at the same time he notices that he sees, although indistinctly, that there are persons sitting on the benches. He cannot, however, so long as he gazes at the selected word, recognize any of them, and might even experience some difficulty in saying whether they were ladies or gentlemen. The power of reading the selected word is called visual acuteness or central vision; the power of recognizing objects at a distance from the central point of fixation is called field or peripheral vision. To some extent the difference between the two is comparable to the difference between the low power and the high power of a microscope. The term "form sense" is often indefinitely applied to visual sensations, and in several of the older textbooks it is used carelessly to mean macular vision.

My present purpose is to call attention to some of the functions of peripheral vision which seem to me to have escaped notice, or at any rate have not been adequately considered. My proposition is that for ordinary manual work visual acuteness, in the proper meaning of the expression, is hardly ever employed; the workman as a rule uses only his field vision.

Visual acuteness has been evaluated; up till now the same has not been done for field vision, and, so far as I can form an opinion, it is never likely to be expressed by any formula. The first man to give a reliable formula for the estimation of visual acuteness was Professor Hermann Snellen of Utrecht, who for many a day was the colleague of Professor Donders in the university of that town. It was a most fortunate combination. Snellen was an ophthalmic clinician of the first rank, and Donders was, in that part of physiology which deals with vision, perhaps only second to Helmholtz himself. His book on the refraction and accommodation of the eye is still a standard book of high authority.

Snellen, after much experimental work, came to the conclusion that, before any object could be seen by a typically healthy and emmetropic eye, it must subtend an angle of one minute on the retina; this implies that, before two objects are distinguishable one from the other, they must be separated by a space which subtends an angle of one minute on the retina. Ultimately he adopted a 5-minute angle as the standard of macular vision, and arranged lines of letters, the largest of which at 60 metres subtend an angle of 5 minutes, while the smallest subtend the same angle at 6 metres. Between these there are lines for the distances of 36 metres, 24 metres, 18 metres, 12 metres, and 9 metres.

Snellen introduced the formula $\mathrm{V}=\frac{d}{\mathrm{D}}$, where $\mathrm{V}$ is the visual acuteness, $d$ the distance between the patient and the types, and $D$ the distance at which the lowest of the lines which the patient is able to read should be read by a normal eye. Thus if at the distance of 6 metres the person being examined is unable to read, or says that he is unable to read, anything smaller than the line which should be read at 18 metres, his vision, or supposed vision, is 6/18 according to Snellen's scale.

In practice it is found that some persons with normal eyes as regards both structure and refraction have better vision than Snellen's standard; but such exceptions, in my experience, are not frequent. Landolt of Paris, who, perhaps as much as anyone, applied the teachings of Helmholtz and Donders to clinical work, while accepting Snellen's standard, altered the test, using instead of letters a broken ring. Either test is quite good; in the main I think Snellen's is the more generally useful, for the break in the ring may correspond with a corneal meridian which is emmetropic-that is, of normal refractive power-while the other meridians of the cornea may be short-sighted or long-sighted.

In the next place I wish to indicate as clearly as I can what I mean by "field of macular vision." Again I am going to take the liberty of using the chairman for experimental purposes. I have on this slip of paper a number of letters printed in parallel vertical and horizontal rows. I now ask the chairman to look steadily at the letter printed at the centre of the slip, and while doing so to draw a line round all the other letters which he sees distinctly while his vision is fixed on the central letter. That gives us the field of binecular macular vision of the person being examined for a particular distance. If the distance of the observer's eye from the paper be known, and also the diameters of the figure drawn to include all the letters that the examinee has seen are measured, then a simple calculation will give the field of macular vision in degrees. So far as I have been able to form an opinion, the field of macular vision, when no accommodation is used, does not extend to two degrees in the general field of vision.

As is well known, the aforementioned binocular general field of vision, as distinct from the macular field in what may be called the maximum horizontal direction, measures rather more than 180 degrees, say about 184 degrees. That means that if the person being examined stands erect and looks at a distant object, so that the axes of vision are horizontal, then if the general field of vision be measured in the plane which passes through the maculae and nodal points of the eyes, the general field is approximately 184 degrees. To put it in nautical language, if $I$ were placed at the centre of a ship in such a position that $I$ could look straight ahead over the bows, keeping the axes of vision horizontal and parallel, I should be able, if my eyes are normal, to have field vision, as distinguished from macular vision, from 2 degrees abaft the starboard beam, right round over the bows to 2 degrees abaft the port beam. The general field of vision is limited in other directions by the prominence of the structures at the upper and inner aspects of the margin of the orbital cavity. Now in the circular arc measuring about 184 degrees not more than 2 degrees correspond to macular vision; the remaining 182 degress are concerned with field vision.

I shall have something more to say about field vision, but meantime I must ask for careful attention to the conditions which obtain in myopia. Suppose a man requires to hold a book to within a few inches of his face before he is able to read its contents, we say that he is short-sighted. For macular vision it is in all cases necessary that the object at which a person is looking-say the book which he is reading - and the image of that object on the retina be at foci conjugate to each other, else reading is impossible. Supposing a man when not using glasses has to bring a newspaper to ten inches from his eyes before he is able to read it, then we know that his remote point of macular vision is ten inches. Cases are not infrequent in which the remote point is much nearer, perhaps only one inch or even less from the eye. Now in such a case it is obvious that there is no macular vision at a greater distance than the farthest distance at which the person can see the book which he is reading; the whole field beyond that distance possesses what has already been called field vision, but does not possess macular. 
The next point which $I$ am going to mention will appeal to those who have no familiarity with optics. It is this: that any man who, when reading without glasses, has to bring a book to a distance of ten inches, or even less, from his eyes before he is able to see to read, experiences no diffeulty in walking about the streets without glasses. For example, in that condition such a man does not require to approach to within ten inches of a tramcar before he sees it; nor has he to pat his eyes to a distance of ten inches from the step before he is able to mount; nor does he require to go to ten inches from a man walking ir the street before he sees him sufficiently chearly to avord collision. All such actions depend on field vision, and not on macular vision, or vistral actiterress, as it is generally called.

It is this field vision which is employed for almost all manual work, and a person engaged in such a form of employment hardly ever uses his macular vision, or only incidentally does so. As above stated, macnlar rision has been expressed by a formula. So far as I am aware field vision has not been thus expressed, and $I$ think that it never will be. Nevertheless, it is of the first importance to those engaged in manual labour and, indeed, to everyone in daily life.

Field vision has the following important functions in health: (1) It has light sense, a function which, up to a point, gives a certain form sense. (2) It has colour sense, which, however, is modified in some persons by the presence of colour-blindness. (3) It has the sense of projection. (4) The periphery of the retina, as well as its central parts, has vision which is very excellent for the perception of movements.

Although a man be very short-sighted he wan readily perceive differences in shades, for that is a matter of the light sense. To ilkustrate my meaning let me narrate an experiment which $I$ made on myself in the month of September, 1926. On a clear although moonless night, towards the end of that month, I made myself myopic by the simple process of putting a pair of 12-inch convex lenses in front of my spectacles for distance, and yet with that arrangement I could from Arinagour in the island of Coll see the Treshnish Islands, the nearest being eight miles away: they would have presented no diffieulty had $I$ been navigating through them. - It was not a pitch dark night, for there was starlight; had it been so nobody, no matter what the condition of his visual apparatus, would have seen anything, but the feeble amount of light present was differently reflected by the sky and by the islands. Yet, with the optical arrangement which $\mathbf{I}$ was wearine at the time, I could not have read a book at a greater distance than twelve inches from my eyes. Short-sighterlness, even a high degree of short-sightedness, does not per se present any diffieulty in the seeing of colours. Thus the short-sighted man negotiating the tramear would see the vehicle some hundreds of yards from him; he would do so because, for the most part, ears are in movement, and, moreover, the reflection from its surface would affect his light sense differently from the objects surrounding it. Further, from the differences in the colours of the cars, he would most likely be abfe to determine if it was the car that was going to suit his purpose. A shortsighted person is nnable to read an ifluminated divection notice on the front of a car without the aid of glasses, but has no difficulty whatever with a coloured light, unless, indeed, he is colour-blind.

Projection is one of the most important functions of vision. When the point at which the person is looking is straight in front then the principal axis of each eye is cirected to it, and it is seen in what may be ealled its true position, but in addition to that, in binocular vision, not only can the position of the object, the image of whieh is formed on the macula of each eye, be definitely fixed, bat while the person is steadily looking at this object. he can at the same time quite accurately point to other objects in the room. Let us suppose that an object is lying to the right of the abserver when he is looking at the point of fixation; then its image is formed on the nasal side of the right retina and on the temporal side of the left retina, and these two stimulations, one on each retina, give rise in health to single binocular vision. Such points are said to be homologous.

But the same condition is found to exist in monocular vision. If I were to shut one eye and look steadily at an. object in front of me, I could quite easily point to other objects in the room. From the point of view of compensation for the loss of an eye this is a matter of great importance. In the early days of workmen's compensation I was much enployed on behalf of certain firms to examine persons who had sustained eye injuries, and the mention of two cases will show the importance of the subject. One of them was that of a man who had lost an eye in a large factory in a town not far from Glasgow. The remaining eye was admitted to be good. I caused search to be made, and it transpired that quite a number of men who were each possessed of one useful oye had worked in the same and other factories in that neighbourhood; their pay sheets were quite as good as those of their more. fortunate brethren.

The same question arose in connexion with a miner who had lost an eve at his work. Again the pay sheets were produced of a number of colliers similarly situated as regards vision, and it was found that the amounts earned by these men compared favourably with the amounts earned by their fellow workmen. At the moment I cannot name any form of marrual work which cannot be undertaken by a man who has only one healthy eye.

Another question arises, and it is: Given that a workman has lost an eye at a particularly hazardous occupation, should he be compelled to risk the remaining eye at the same occupation? Persoranly I would answer that question in the negative; he ought not to be foreed to do so. At the same time there would require to be a careful definition of what constitutes hazardous employment.

Mention must be made of another important difference between macular vision and general field vision: it is that if errors of refraction exist they must be very carefully corrected for macular vision, but do not, within wide limits, require to be corrected at all for general field vision. Had time permitted $I$ would have elaborated this point, but I must content myself by relating a few examples, which relation will, I think, convey my meaning to my audience.

1. To return to our supposed case of a man who, owing to his short-sightedness, cannot read a book at a greater distance than ten inches, yet who is able, with suitable glasses, to read the smallest of Snellen's types at the proper distance of twenty feet; such a man, although unable to read ordinary type at a greater distance than a few inches with the naked eye, can without spectacles or eyeglasses perfectly well make out objects at very considerable distances, and he sees them with sufficient distincturess to enable him to locate them even when they are far off, and to avoid them when they are near. In other words, visual efficiency cannot be expressed in terms of visual acnteness, using the phrase "visual acuteness" as synonymous with macular vision. It is quite untrue to say that because a man cannot read all Snellen's types at twenty feet he will not be able to make out in object at sea, perhaps miles away. Is already narrated, when I mado myself so shortsighted that $I$ could not read a book at a greater distance than twelve inches I could easily make out the presence of islands eight miles away.

As regards road trafice, it does not matter what letters a driver can read in a consulting room, but it does matter that be can see other traficic on the road at a sufficient distance to enable him to avoid it; the one is not a test of the other.

The vision required at sea and on the road is field vision, and not nacular. No doubt a cortain amount of macular vision is required at sea for such purposes as reading of tide tables and the examining of eharts.

2. Nor does the presence of an uncorrected dofect in the refraction of the eye make any difference to the individual in distinguishing colonrs. A person with an error of refraction can, without glasses, distinguish colours quite as well as he can with them, for the recognition of colours is for the most part a matter of field vision and not of macular. 
3. The same remark holds true about the light sense: the distinction of shades is quite good in peripheral vision, and that whether the individual is or is not wearing glasses. Indeed, the light sense is more active without glasses than with them, for about 15 per cent. of the light that is incident on the surface of a spectacle lens is reflected and never enter's the ere at all. Where the initial amount of light is small the effect of the loss of such a percentage is considerable.

I hope the preceding remarks have made the essential difference between visual acuteness and field vision quite clear. I propose to conclude by giving a few examples in support of the view which $I$ have already expressed, that manual work is for the most part a matter of field vision and not of macular.

In the first place take coal miners. At the Annual Meeting of the British Medical Association in Toronto, in 1906, I mentioned the cases of some miners who had very high degrees of short-sightedness-some with the far point of macular vision at only two inches from their eyes-and yet their pay sheets showed that they were in no way handicapped. Since that time I have seen miners whose far points of macular vision were ten inches or under who had no difficulty with their work. I have recorded cases in which the far point of reading vision was at two inches from the eye, and yet the pay sheets showed no diminution of earning power. One case I particularly remember, in which a young miner desired to get work above ground and applied to be taken on as a stoker by one of the railways. It was then found that he had shortsightedness and that his far point of reading distance was at fifteen inches from his eyes. Till that examination took place he had no idea that there was anything wrong. It is needless to say that his services were not accepted. ${ }^{1}$

A few vears ago I made an investigation as to the causes of blindness in about twelve hundred eases. The results of that investigation were published under the auspices of the medical officer of health for the city of Glasgow. I have selected a few of them as illustrative of the truth of the view which $I$ have been enunciatingnamely, that the importance of field vision has not been adequately considered. One or two of the cases which I an going to mention were seen at the clinic of the Glasgow and West of Scotland Mission to the Outcloor Blind.

1. A man, aged 70 , who, at the time of my secing him, was quite blind as a consequence of injury to the back of his head. Therefore for some years be had not had either macular or Therefore for some years he had not had either macular of
field vision. The interesting point is that he had previously been extremely short-sighted, so that the conjugate of each retina was at a less distance than two inches from the front of the corresponding eye. and yet, in that condition, he maintained himself either as a dock labourer or as a stoker on board a steamship up to the time of the accident which deprived him of sight, and he did that work without any correction of his errors by glasses.

2. A man in the employment of the Glasgow Mission to the Outdoor Blind. This man lost an eye a number of years ago. With the remaining eye he sees the type called "brilliant" by printers at rather less than two inches from the eye, but not at a greater distance. Till he entered his present employment he was regularly at work at the bottom of a eoal pit.

3. A man whose conjugate to each retina was twelve inches from the cornea, yet he was quite able, till he became nearly blind from choroiditis, to work as a carter in the streets of Glasgow.

4. In this case there is also a high degree of short-sightedness, the conjugate of the retina being at three inches from the man's eve, yet all through the war he worked steadily in a hangar of the Royal Air Force.

5. This workman has also an extreme degree of short-sightedness, the conjugate of his retina being not more than three inches in front of lais cornea, yet he was, during the war, ealisted in H.M. forces and served abroad.

The above cases show that, although a man's far point of reading vision may be only a few inches from his eyein some cases at less than two-yet the field rision is quite sufficient to enable the person to undertake many forms of ordinary work.

Amongst those whom I have entered in my special notebook there are recorded some cases where the conjugate of the retina is negative - that is, it is situated behind the retina, and the light leaving the eye from a point source

${ }^{1}$ See British Medical Journal, 1906, ii, p. 1865. on the retina emerges from the eye in a divergent pencil. For this form of refraction error the same condition is true--it makes rery little or no difference so far as manual work is concerned, but it does cause much trouble for nearat-hand vision, and interferes materially with a person's ability to read and to write.

I might bring before your notice many other cases of persons possessed of refraction errors who had no difficulty whaterer in carning their living and in getting about much as other people. It is quite certain that for their work they dich not employ visual acuteness, but only field vision.

Now 1 wish to bring to notice a few cases of a different kincl, but which also support the view that field vision is of great importance for most forms of manual work.

A man was operated on in both eyes for congenital cataract. He has no visual acuteness-that is, be eannot see to read at any distance with or without glasses, and never will-yet he has excellent field vision and is able, without any attendant, to get about quite freely.

Bilateral congenital cataract-an opacity in each lens in infancy, or at any rate in early childhood-if extensive, prevents the formation of retinal images and therefore, if not remedied by suitable treatment, the patient will never have nacular vision. At the same time ordinary daylight reaches the retinas notwithstanding the opaque lenses, and a person so afflicted will be found to have useful field vision, although destitute of macular vision.

One of the most extraordinary cases that $I$ have ever seen is the following.

A man, aged 25, had his left eye removed early in life on account of some disease. The right eye has congenital nystagmus, and, in addition to that, the lens of the right is, as the result of an injury received a good number of years ago, dislocated. With a convex lens of about 7 degrees focal length held close to the eye he can make out bourgeois type when that type is held at an
inch in front of the lens. He cannot, of course, with any glass inch in front of the lens. He cannot, of course, with any glass see even the largest of Snellen's letters at twenty feet. He lives
in a town in the South of Scotland, and yet, handicapped as he in a town in the South of Scotland, and yet, handicapped as he
is, he can walk about quite frecly. He also says that he cycles a good deal, but he finds cycling increasingly difficult on account of motor traffic.

One other set of cases will further illustrate the fact that macular vision is not used by working men. When a man is driving paling stobs he swings a long-handed mallet over his shoulder; that action entirely prevents the image of the object which he is going to strike being focused on the nateula. Such work is entirely a matter of projection; and the sense of projection is as much a function of field vision as it is of macular.

Another example of the same thing is the swinging of a heary hanmer by a blacksmith. In this instance, as in the previous onc, the action depends upon the sense of projection and on the mental estimation of distance.

Macular vision, and therefore macular efficiency, can be expressed by means of a formula, and, as already pointed out, it is seriously impaired by errors of refraction. Field vision, and therefore field efficiency, cannot be expressed by any formula, and for field vision, within wide limits, it is not necessary to coirect errors of refraction.

Field vision is largely a matter of projection and of mental interpretation. In one of his writings Helmbeltz plainiy stated that the eyes merely receive stimuli of various kinds, but that it is left to the mind to interpret them. After all, it is the mind that really soes and not the eres, just as it is a person who hears when using a telephone and not the apparatus.

There are other points on which I should have liked to say a great deal, but I have only time for one other remark, and it is that if you test men for work by letter's you will reject a number who are quite capable of doing a great deal. For example, at the noment I know a gentleman who has a considerable degree of short-sightedness, who cannot see to read at a greater distance than eighteen inches and certainly would not have anything like six twenty-fourths of Snellen's types for distant vision, and yet he has for many years driven a motor car and has not had any accident. Undoubtedly evesight can be tested for such occupations as reading and writing by Sinellen's letter's, but you cannot test efficiency for manual work by auy such contrivance. The only test of efficiency is as to whether a man has or has not done the work; if he has done it in the past there is no reason why he should not 
do it in the future, but no prima facie statement without such investigations is of any value. If you reject persons who are capable of work because they are not able to read certain letters at a particular distance you are going to throw a number of men out of employment who might otherwiso be pursuing occupations remunerative to themselves and beneficial to the community, and add materially to the number of the unemployed, although not unemployable.

\section{A PLEA FOR A NATIONAL LABORATORY FOR THE STUDY OF MENTAL ARN(ORMALITY.}

R. J. A. BEIRY, M.D., F.R.C.S., F.R.S.ED.,

PROFESSOR OF ANATOMY, INCZUDING HISTOLOGY, IN TIIE UNIVERSITY OF MELBOURNE; HONORARY PSYCIIIATRIST TO THE CHILDREN'S WELFARE DEPARTMENT AND THE CHILDREN'S HOSPITAL, MELBOURNE.

By the publication in 1914 of Dr. Shaw Bolton's The Brain in Health and Disease and of Dr. G. A. Watson's equally important work on cortical stratification and cerebral function in horizontal layers, it appears to be established that developmental errors in the cellular elements of the several horizontal layers of the cerebral cortex underlie many of those antisocial reactions characteristic of criminality and some of the insanities.

Almost every branch of study shows that the principles underlying the structure of the nervous system are the same in all vertebrates. Once fertilization is accomplished the single-celled ovum undergoes a rapid process of cell division, and these cells resolve themselves into three great types-somatic, reproductive, and nervous. As regards the last highly specializer cells (neurons), it is now generally believed that, though they remain throughout life anatomically independent, they cannot function physiologically unless they become combined into chains and arcs. A neuronic arc usually comprises three nerve elementsa receptor, afferent, or sensory neuron conducting from tho periphery centrally; an interposed, connecting, or internuncial neuron; and an effector, efferent, or motor neuron. Medical attention has, perhaps, been too exclusively focused on the long conducting receptor and effector neurons, yet it is the internuncial neurons which, when present in sufficient numbers, result in the phenomena termed " mind."

The researches and investigations of Golgi, Cajal, Mott, Bolton, Watson, and many others suggest, if they do not actually prove, that all mental phenomena-speech, reason, memory, and the like-are the products of many thousands of millions of cerebral neurons linked together in arcs and functional units, and that these millions of cerebral cells appear to be internuncial in type.

In the spinal cord the dorsal spinal nerve roots are composed of receptor neurons. The connecting associational and commissural neurons are internuncial in character, and the ventral spinal nerve roots transmit the effector neurons of the arcs. In the cerebellum the receptor (proprioceptor) neurons chiefly traverse the inferior cerebellar peduncles. The internuncial neurons are of the suprasegmental type-that is, the associational and commissural neurons of the spinal cord are replaced by small granular cells strictly confined to the grey matter and forming the bulk of the cerebellar cortex, and greatly outnumbering all other neurons in the cerebellum. The relatively few Purkinje cells constitute the effector cells of the cerebellar neuronic arcs. The cerebellum is thus distinguished by a totally different type of internuncial or connecting neuron, and the associational and commissural spinal cord types are completely absent, being replaced, as stated, by the granular cell type. The fact that anatomical nomenclature has differentiated these granular cells as basket, stellate, Golgi Type II, and the like, should not be allowed to divert attention from the fact that all are interposed between the receptor and effector neurons of the cerebellum and are thus internuncial in character. Cerebellar cortical construction thus compels the conclusion that the function of these numerous cerebellar internuncial cells must be that of storage of nerve impulse; hence the cere- bellum is, clinically and functionally, a great storehouse of nerve energy, and this energy is liberated under the control of the cerebral cortex exercised through the corticoponto-cerebellar pathway, and comes into action in every voluntary muscular movement.

The cerebral cortex fulfils functions so different from those of either spinal cord or cerebellum as to suggest that a totally different construction must be employed by nature, and yet such is not the case. The cerebral cortex, in its structure, simply repeats both spinal cord and cerebellar types, the essential difference being that there are far more associational and commissural internuncial (spinal cord type) neurons, and granular (cerebellar type) ones in the cerebral cortex than in either spinal cord or cerebellum.

In the cerebral cortex the thalamo-cortical fibres form the receptor limbs of the neuronic arcs. The projection systems represent the effector sides of tho arcs. There are thus left the enormous numbers of granular cells, and the even more numerous pyramidal and polymorphic cells, the axous of many of which form the associational and commissural systems of the brain, as the representatives of the connecting or internuncial units of the neuronic arcs. It is not, as yet, clear whether these numerous cerebral neurons are all to be regarded as the internuncial neurons of the primary cerebral neuronic arcs, or whether they form secondary neuronic arcs within the primaries. All the evidence, however, seems to warrant the conclusion that it is these presumably internuncial cortical neurons which, by storing up all those numerous nerve impulses which continually bombard the brain from birth to death, act as the physical basis of memory, and therefore of speech, reason, judgement, and of all mental phenomena.

Recent research, particularly that of Bolton and Watson, has shown that the cell bodies of those cerebral neurons which aro almost certainly internuncial in character and function tend to arrange themselves in the cerebral cortex in definitely stratified layers, and that this horizontal stratification has a subtle, but profoundly important, functional significance. Excluding the fibre laminae of the cerebral cortex, which are not germane to the present argument, tho human cerebral cortex is composed of three layers of cell bodies-pyramidal cells on the exterior, granular cells in the middle, and polymorphic on the interior next the white matter. The polymorphic cells on the interior, termed by Watson the infragranular cortex, are present in all mammals, and are believed to be the nerve elements controlling or concerned with the purely animal functions of the body, such as the acquisition of food and the activities of sex-that is, the infragranular cortex appears to be the brain of the preservation of the individual and the perpetuation of the species.

The pyramidal cells on the exterior are best and most largely developed in man, and man is the only animal who possesses a sufficiency of such pyramidal cells to give him the power of voluntarily inhibiting the animai functions of the infragranular cortex. The layer is termed by Watson the supragranular cortex, and the cell bodies are of the kind commonly and always associated with the effector functions of inhibition. When normally doveloped man can, therefore, exercise a voluntary control over the animal instincts of sex, acquisition, and self-gratification; and society, in the interests of all, expects him to do so. It is illogical and erroneous to attribute mental evils to a purely physiological process like repression, for repression is a human attribute, and the welfare of the nation calls for its exercise. If, however, the individual possesses a relatively undeveloped supragranular controlling cortex it necessarily follows that his powers of control are diminished, and he is more likely to react to his environment on the more purely animal basis of acquisition, sexual gratification, and lack of appreciation of the consequences of these reactions. It is a striking fact that at least 75 per cent. of those antisocial reactions against which society seeks to protect itself, and known as "crimes," are directed against the person or the property-that is, sex and acquisition. It is equally striking that Bolton and others have been able to demonstrate that these antisocial personalities are found, after death, to possess a thinner supragranular cortex-that is, one with fewer pyramidal 